\title{
Mineral Nitrogen and Microbial Biomass Dynamics under Different Acid Soil Management Practices for Maize Production
}

\author{
Richard N. Onwonga (Correponding author) \\ Department of Land Resource Management and Agricultural Technology \\ University of Nairobi. P.O. Box 29053-00625, Nairobi, Kenya \\ Tel: 254-725-828-254Ｅ-mail: onwongarichard@yahoo.com
}

Joyce J. Lelei

Department of Crops, Horticulture and Soil Science

Egerton University, P.O. Box 536, Njoro, Kenya

Benson B. Mochoge

Department of Agriculture Resource Management, Kenyatta University

P.O. Box 43844, Nairobi, Kenya

\begin{abstract}
Field and laboratory incubation studies were conducted to determine the effect of different acid soil management practices; liming (L), combined $\mathrm{N}$ and $\mathrm{P}$ fertilizers (NP), and goat manure (M) application, for maize production on the dynamics of mineral $\mathrm{N}$, microbial biomass nitrogen (MBN) and microbial biomass carbon (MBC). A randomised complete block design with a $2^{3}$ factorial arrangement replicated thrice was used. The factors, each at two levels, were: NP fertilizers applied as triple superphosphate $\left(0\right.$ and $\left.75 \mathrm{~kg} \mathrm{ha}^{-1}\right)$, and urea $\left(0\right.$ and $\left.50 \mathrm{~kg} \mathrm{ha}^{-1}\right), \mathrm{L}\left(0\right.$ and $\left.2.5 \mathrm{tha}^{-1}\right)$ and M $\left(0\right.$ and $\left.5 \mathrm{t} \mathrm{ha}^{-1}\right)$ giving a total of eight treatments; L, M, NP, LM, LNP, MNP, LMNP and C (control). Soil samples for determination of mineral $\mathrm{N}, \mathrm{MBC}$ and $\mathrm{MBN}$ were collected from the $0-15$ and $15-30 \mathrm{~cm}$ depths at seedling, tasselling, and maturity stages of maize growth and after $0,15,30,60,120$ and 240 days of laboratory incubation of soils obtained from the same field.

The NP treatment had significantly $(\mathrm{P}<0.5)$ higher levels of mineral $\mathrm{N}$ in both depths at all stages of maize growth, followed by MNP and LMNP. The net mineralized N ( $\mu \mathrm{gN} / \mathrm{g}$ dry soil) for the incubated soil followed the order LMNP, MNP, LM, M, L, LNP, C and NP for the two depths. The MNP, LMNP and M treatments had significantly higher MBC and MBN for both field and incubated soils. The correlations between mineral $\mathrm{N}$ and MBN were positive but non-significant at seedling and maturity stages of maize growth in the $0-15 \mathrm{~cm}$ depth and at seedling and tasselling stages in the 15-30 cm depth. The correlations between MBN and Mineral $\mathrm{N}$ for both depths and sampling periods were positive and significant for the incubated soils, The maize grain yield increases (\%) above control were 43, 36.4, 31.1, 25.3, 21.9, 13.7 and 3.0 for LMNP, MNP, NP, M, LNP, LM and L treatments, respectively.

Application of LMNP and MNP treatments enhanced mineral N, MBC and MBN and concomitantly soil quality and productivity as gauged from the improved maize yields in the respective treatments. Combining manure, lime and chemical fertilizers and /or manure and chemical fertilizers is thus a promising alternative to developing a more sustainable acid soil management strategy for increased maize production in Molo district, Kenya.
\end{abstract}

Keywords: Acid soils, Inorganic fertilizers, Lime, Manure, Microbial Carbon, Microbial nitrogen, Mineral nitrogen, Kenya

\section{Introduction}

Soil degradation occurs due to nutrient depletion, soil structure deterioration, acidification and sub-optimal addition of organic and inorganic fertilizer to soil. Acidification of soil results in loss of exchangeable $\mathrm{Ca}^{2+}$ and $\mathrm{Mg}^{2+}$, a decrease in effective cation exchange capacity, and an increase in exchangeable $\mathrm{Al}^{3+}$ (Graham et al., 2002). An adverse effect of soil acidification is decreased water and nutrient retention capacity of soils and reduced biotic activity (Kinraide, 2003). 
Such adverse soil condition can lead to decline in soil quality and crop yields. Numerous properties characterizing the status of soil microbial biomass, activity and nutrient content have been suggested as indicators of soil quality (Doran and Parkin, 1994). Although microbial biomass only forms a small fraction of soil organic matter, it contributes to agricultural sustainability because its high turnover rate is responsible for nutrient release and therefore promotes plant uptake (Smith et al., 1993).

Soil organic matter is thus an important component of soil quality and productivity. Nevertheless, its measurement alone does not adequately reflect changes in soil quality and nutrient status (Mathers et al., 2000; Chen et al., 2004). Measurements of biologically active fractions of organic matter, such as microbial biomass carbon (MBC) and nitrogen $(\mathrm{MBN})$, and potential $\mathrm{C}$ and $\mathrm{N}$ mineralization better reflects changes in soil quality and productivity that alter nutrient dynamics (Hole et al., 2005). Because it is living, the microbial biomass responds much more quickly to changing soil conditions, particularly decrease or increase in plant or animal residues, than does soil organic matter as a whole. Measurable changes in microbial biomass would thus reflect changes in soil fertility due, for example, to changes in the total pool of soil organic matter (Brookes, 1995; El-Ghamry et al., 2001).

The soil microbial biomass (MBC and MBN) is the active component of the soil organic pool playing an important role in nutrient cycling and plant nutrition and functioning of different ecosystems. It is responsible for organic matter decomposition thus affecting soil nutrient content and, consequently, primary productivity in most biogeochemical processes in terrestrial ecosystems (Gregorich et al., 2000; Haney et al., 2001). Applying organic amendments to soil not only increases the total organic carbon content and its different fractions but also has a series of effects on microbial proliferation and activity (Tejada et al., 2006; Ros et al., 2003). Soil microbial biomass is undoubtedly a valuable tool for understanding and predicting changes in soil fertility management and associated soil conditions such as nutrient dynamics and soil reaction (Sharma et al., 2004; Yougun et al., 2007). It has assumed greater significance and increasing interest in its determination (Azam et al., 2003).

Knowledge of mineral N, MBC and MBN dynamics is particularly critical in the management of acid soils, to reverse declining soil organic matter content and restore soil fertility. There is hitherto a dearth of literature on the effects of various acid soil management practices for maize production on soil mineral $\mathrm{N}$ and soil microbial biomass dynamics for Molo district of the central Rift valley province, Kenya. Most of the studies that have been carried out in the district (Lelei et al., 2006; Cheruyoit et al., 2003) have mainly focused on the effects of soil amendments on nutrient availability, soil $\mathrm{pH}$ changes and maize performance.

The aim of the current study was therefore to determine the effect of different acid soil management practices for maize production on the dynamics of mineral N, MBN and MBC and maize yield.

\section{Materials and methods}

\subsection{Site description}

The field study was conducted at the Kenya Agricultural Research Institute field station located $5 \mathrm{~km}$ from Molo Town in Molo District. The site $\left(0^{0} 12^{1} \mathrm{~S}, 35^{0} 41^{1} \mathrm{E}\right)$ is at an elevation of $2500 \mathrm{~m}$ with a gently undulating slope $(0-5 \%)$. The rainfall distribution is bimodal in nature with the long rains occurring from March to July/August and short rains from September/October to December. The annual rainfall and mean temperature during the experimental period were 1450 $\mathrm{mm}$ and $17.5^{\circ} \mathrm{C}$, respectively. The soils are acidic, well drained, deep, dark reddish brown with a mollic A horizon, and are classified as mollic Andosols (FAO/UNESCO, 1990). The measured initial characteristics of the top soil were $1.74 \%$ organic carbon, $0.18 \%$ total $\mathrm{N}, 3.20 \mathrm{ppm}$ available $\mathrm{P}$ (Mehlich), $\mathrm{pH}\left(\mathrm{H}_{2} \mathrm{O}\right)$ of 4.87 and clay texture.

\subsection{Experimental design, treatments and statistical analysis}

A randomized complete block design (RCBD) with a $2^{3}$ factorial arrangement replicated thrice was used. The factors, each at two levels, were: combined $\mathrm{N}$ and P fertilizers (NP) applied as triple superphosphate $\left(0\right.$ and $\left.75 \mathrm{~kg} \mathrm{ha}^{-1}\right)$ and urea $\left(0\right.$ and $\left.50 \mathrm{~kg} \mathrm{ha}^{-1}\right)$, lime $\left(\mathrm{L}, 0\right.$ and $\left.2.5 \mathrm{tha}^{-1}\right)$ applied as $\mathrm{CaCO}_{3}$, and goat manure $\left(\mathrm{M}, 0\right.$ and $\left.5 \mathrm{tha}^{-1}\right)$ giving a total of eight treatments; C (control, with no soil amendment applied), L, M, NP, LM, LNP, MNP and LMNP. The manure $(1.2 \% \mathrm{~N})$ and Urea (46\%) supplied 60 and $23 \mathrm{~kg} \mathrm{~N} \mathrm{ha}^{-1}$, respectively. The calculated amounts of $\mathrm{N}$ supplied $\left(\mathrm{kg} \mathrm{N} \mathrm{ha}^{-1}\right)$ by the different combinations were; LM (60), LNP (23), MNP (93), LMNP (93). These amounts were higher than the current farmer practices. Farmers use soluble but acid forming Diammonium phosphate (DAP; $18 \% \mathrm{~N}$ ) fertilizer in small amounts of 20-30 $\mathrm{kg} \mathrm{ha}^{-1}$ against the recommended rate of $60 \mathrm{~kg} \mathrm{~N}^{-1}$ (FURP, 1994, Lelei et al.,2006).

Soil samples for the incubation study, conducted at the Egerton University soil science laboratories, were obtained from the experimental site. The soil were sampled at $0-15$ and $15-30 \mathrm{~cm}$ soil depths dug out from two profile pits, and mixed thoroughly according to the respective depths to get one composite sample for each depth. Eight soil samples $(2 \mathrm{~kg}$ each) obtained from each composite sample, were treated similarly as for the field study. The samples were, incubated, in triplicate, in polythene bags in the laboratory at room temperature $\left(25^{\circ} \mathrm{C}\right)$ and moisture adjusted to field capacity. 
The results obtained were subjected to analysis of variance (ANOVA) using SPSS version 11.00 (SPSS. 2003). The means were separated at $0.5 \%$ least significant level (LSD). Correlation analysis, to generate correlation coefficients, was done to determine the relationships between mineral $\mathrm{N}$ and $\mathrm{MBC}$ and MBN. The correlation coefficients were computed using the Pearson's correlation coefficient.

\subsection{Agronomic Practices}

Prior to the experiment, the field had been under a two month weedy fallow and had maize stubble from the previous crop. Land was prepared manually, using hand hoes, followed by secondary cultivation which involved raking and levelling of the seedbed. The maize stubble was removed manually before application of treatments. Lime and goat Manure were applied two weeks (immediately after secondary cultivation) prior to planting of maize (hybrid 614, eight months maturity period) through broadcasting and banding, respectively and thoroughly mixed with soil. Triple superphosphate (TSP) fertilizer was applied per hill and mixed well with soil at planting of maize while urea was top-dressed along maize rows one month after planting. Three maize seeds were sown at each planting hole at a spacing of $60 \times 75 \mathrm{~cm}$ in all plots each measuring $4 \times 4.5 \mathrm{~m}$. Four weeks after planting the seedlings were thinned to two per hill, thereby retaining the recommended population of 44,444 maize plants/ha. Aladrin dust (25\%) and dipterex were used to control cutworms and stalk borers, respectively. Weeds were regularly controlled by hand weeding.

\subsection{Soil sampling and analysis}

Soil sampling: Soil samples for mineral N, MBC and MBN determination were obtained from the 0-15 and $15-30 \mathrm{~cm}$ depths before maize sowing (initial sampling) and at maize; seedling (Zadoks stage 25), tasselling (Zadoks stage 65), and maturity (Zadoks stage 98-99) stages of maize growth (Zadoks et al., 1974) at random between the plants within a row in every plot. Four auguring were done in every plot and the soil bulked together according to the respective depths to get one composite sample for each depth. For the incubation experiment, soil sampling, for mineral N, MBN and MBC analysis was done at $0,15,30,60,120$ and 240 days of incubation.

Soil analysis: Soil microbial biomass C (MBC) and N (MBN) were determined by the chloroform-fumigation extraction method (Joergensen, 1996). Field-moist soils were fumigated with ethanol-free chloroform for $24 \mathrm{~h}$. Both fumigated and non-fumigated soils were extracted with $0.5 \mathrm{M} \mathrm{K}_{2} \mathrm{SO}_{4}$ (for $\mathrm{MBC}$ and $\mathrm{MBN}$ ) by shaking for 30 minutes. MBC was determined by a heated sulfuric acid dichromate digestion, and MBN was analyzed in a persulfate digestion of the extracts and measured total $\mathrm{N}$ using a modification of the micro-Kjeldahl method. The factors used to convert the extracted organic $\mathrm{C}$ and $\mathrm{N}$ to $\mathrm{MBC}$ and $\mathrm{MBN}$ were 0.38 and 0.45 respectively (Brookes et al., 1985; Vance et al., 1987). Inorganic $\mathrm{N}\left(\mathrm{NH}_{4}^{+}-\mathrm{N}\right.$ and $\left.\mathrm{NO}_{3}^{-}-\mathrm{N}\right)$ was extracted with $2 \mathrm{M} \mathrm{KCl}$ and determined by colorimetrical methods (Okalebo et al., 2002).

\section{Results and discussion}

\subsection{Mineral $N$ at the different stages of maize growth}

The initial (background $\mathrm{N}$ ) mineral $\mathrm{N}$ measured, prior to maize sowing, in the 0-15 and 15-30 $\mathrm{cm}$ depths was 49 and 34 $\mu \mathrm{gN} / \mathrm{g}$ dry soil, respectively. There was a marked decline in mineral-N across sampling times in all treatments and depths with progression of maize growth (Table 1). NP and MNP treatment had significantly $(\mathrm{P}<0.5)$ higher levels of total mineral $\mathrm{N}(0-30 \mathrm{~cm}$ depth) than the other treatments at all stages of maize growth (Table1). Mineral-N was significantly higher in the treatments containing NP, MNP, LM and LMNP at maize maturity.

The high mineral-N measured during the initial soil sampling could be attributed to the flush of nitrates formed at the onset of the main rains. Nitrate frequently accumulates in tropical soils during the onset of the rains following a dry season (Scherer et al., 1992). The observed declines in mineral N in the soil profile with sampling time (Table 1) could be due to increased crop uptake during development. Hybrid 614, a long maturing maize variety is a high responsive hybrid with a high nutrient requirement. Tsai et el. (2009) reported that the amount of $\mathrm{N}$ taken up varied with hybrids and was higher in high responsive hybrids. Sangoi et al. (2001) similarly reported that older hybrids took up more N and presented higher values of shoot dry matter at flowering. Kamoni et al. (2000) had also found that $\mathrm{N}$ is taken up by maize throughout the growing season with maximum uptake 10 days before tasselling to 25 to 30 days after tasselling. The sudden increase in mineral $\mathrm{N}$ for NP treatment at seedling stage was as a direct result of the top dressed urea (Tejada et al., 2008).

The significantly higher mineral N in NP and MNP treatments $(0-30 \mathrm{~cm}$ depth) than LM, LNP and LMNP at all stages of maize growth is directly attributable to the direct $\mathrm{N}$ supply from the fertilizer applied and subsequent manure mineralization. Bending et al. (2002) had also found that organic materials applied alone or in combination with inorganic fertilizer gave greater residual soil fertility in terms of increase in organic carbon content and the available $\mathrm{N}$. Magill and Alber (2000) reported that immobilization can occur upon organic fertilization of the soil depending on the carbon-nitrogen ratio of the substrate. The low mineral N in LMNP could be due to increased competition for nutrient uptake between plant and microorganisms. Although organic amendments can provide available nutrients for plants, the 
coupling of carbon and nutrient transformation during organic matter decomposition strongly interacts with plant nutrient uptake, leading to a competition for nutrients between soil microorganisms and plants (Kaye and Hart, 1997).

The decrease in mineral $\mathrm{N}$ with depth is attributable to better substrate supply in the upper soil depth than the sub-soil and the rhizosphere effect. This observation is in agreement with Young and Ritz (2000) and Kladivko (2001) who reported that soil microbial biomass (SMB) as well as mineralization of carbon and nitrogen tended to be greater in the upper layers of the soil and decrease with depth. Yong-Liang et al. (2001) reported that there exists a relative nitrogen accumulation in the rhizosphere. Mineralization of rhizodeposition provides a possibility for 'recycling' organically bound nutrients such as $\mathrm{N}$ and $\mathrm{P}$ (Marschner et al., 2003).

\section{$3.2 M B C$ and $M B N$ during maize growth as affected by treatment application}

There were variations in soil MBN and MBC with progression of plant growth in all treatments and depths except for the $\mathrm{C}$ and $\mathrm{L}$ treatments where the variations were minimal and insignificant (Table 2). MBN and MBC were high at the initial sampling stage in the $0-15 \mathrm{~cm}(23.90,18.30)$ and $15-30 \mathrm{~cm}(146.90,116.80)$, depth respectively (Table 2). The MBN and MBC declined slightly at tasselling but increased substantially towards maturity. The treatments MNP, LMNP and M had significantly $(\mathrm{P}<0.05)$ higher MBN and MBC than the rest of the treatments at all sampling depths and maize growth stages (Table 2). This could be due to enhanced soil conditions and availability of substrates with application of the soil amendments and probably due to the positive interaction between M, NP and L. Compared against the control treatment, the M treatment had the highest (47.8 to 51.2\%) MBN across sampling times and depths. MBN was found to be much lower on average when compared against control treatment across depths and sampling times especially in treatments where the NP fertilizer; LNP (16.4-31.08\%), MNP (2.64-37.96\%), LMNP (20.34-48.52\%) was applied.

The fluctuations in microbial $\mathrm{N}$ and $\mathrm{C}$ pool (Table 2) with progression of maize growth could be due to frequent environmental changes in the soil which would have had an impact on soil moisture status and temperature. These changes could have continually affected the activities of microbes and uptake of nutrients by the maize crop. According to Poudel et al. (2002) soil microbial properties are influenced by variations in soil moisture, temperature, crop type and nutrient supply as well as immediate farming practices, such as fertilization and cultivation. Differences between the sampling dates could also be responsible for the observed fluctuations in microbial biomass. This assertion is in agreement with that one of Cerny et al. (2003) who had found wide fluctuations in MBC and MBN across seasons with decreases coinciding with periods of high plant $\mathrm{N}$ demand and vice versa.

Minimal fluctuations of MBN and MBC in the $\mathrm{C}$ and $\mathrm{L}$ treatments suggests low microbial turnover due to soil acidity and insufficient time for neutralization of soil acidity by lime. Liu et al. (2004) had reported that acid soils limit microbial growth. However, most experiments in which $\mathrm{pH}$ has been manipulated by either acid or lime addition have been relatively short term, and so the soil microbial biomass (SMB) may not have had time to adjust to the radically altered conditions (Wheeler et al., 1997; Curtin et al., 1998). In many soils, lime application has the consequence of solubilizing organic matter. This enhances the availability of organic nitrogen to the plant by facilitating the action of microbiota on soil organic matter decomposition. So any observed short-term microbial responses may be due to this increased release as opposed to a direct effect of $\mathrm{pH}$ on the microbes themselves (Curtin et al., 1998).

Decline in MBN and MBC with depth is attributable to the declining organic substrates with increase in depth. Organic matter supports most micro-organisms in terms of energy and protoplasmic build up. Girvan et al. (2003) and Hole et al. (2005) states that the size of MBC is regulated by substrate availability necessary for providing energy for the maintenance of microbes. Kirchner et al. (1993) had also observed that microbial populations and activities were greater in the $0-7.5 \mathrm{~cm}$ than $7.5-30 \mathrm{~cm}$ zone and found the differences between the depths to be statistically significant $(\mathrm{P}<0.01)$ for all enzymes, fungal populations and levels of available $\mathrm{N}$.

The high MBN at seedling stage could be due to high rhizosphere activities resulting from initial stages of crop take off and low crop demand. The micro-organisms reimmobilize $\mathrm{N}$ that is mineralized leading to high MBN. These results are in agreement to those of Bremner and Van Kessel (1992) who found high levels of microbial biomass at planting of crops compared to the rest of the season and attributed the same to increases of microbial biomass during periods of low crop demand that reduced loss of $\mathrm{N}$ and other nutrients in soil.

Low MBN at tasseling for all treatments and depths is an indication of enhanced $\mathrm{N}$ uptake by the plant thus limiting mineral N supply to microbial biomass. Kamoni et al. (2000) had reported that maize got most nutrients from the soil at about 10 days before tasselling to 25-30 days after tasselling. Garcia and Rice (1994) had also observed a decrease in MBN accompanied with a transitory decline in inorganic $\mathrm{N}$ which was assimilated by actively growing plant roots. The increase in MBN at harvest therefore reflects reduced uptake of mineral $\mathrm{N}$ by the maize crop due to cessation of crop growth. This is in addition to immobilization of $\mathrm{N}$ into microbial biomass and turnover of root biomass into the soil pool. According to Groffman et al. (1993), $\mathrm{N}$ that is returned to the soil at the end of the growing season is conserved by microbial immobilization. 
The observed increase in MBC at harvest (Table 3) is due to the substrates in form of sloughed root cells, root exudates and leaf fall produced during maize growth. Franzluebbers et al. (1995) found that MBC responded to addition of C substrates from rhizodeposition during the growing season and crop residues at harvest. El-Ghamry et al. (2001) and Tejada et al. (2006); observed maximum levels of microbial biomass later in the growing season and attributed this to $\mathrm{C}$ addition from plant roots.

The high microbial biomass $\mathrm{C}$ and $\mathrm{N}$ levels in treatments; M, MNP and LMNP is attributable to microbial proliferation. Cropping systems that increase inputs of carbon through green manures, cropping sequences or animal wastes have been shown to have more microbes and greater microbial activity than that found in systems that utilize only fertilizer inputs (Buchanan, 1990). Fauci and Dick (1994) reported that soil amended with beef manure had significantly higher MBC, MBN and soil enzyme activities than inorganic $\mathrm{N}$ treatments. It is a well known fact that soil organic $\mathrm{C}$ strongly affects the amount and activity of soil microbial biomass (Francisco et al., 2005).

\subsection{Incubation study}

\subsubsection{Mineral $\mathrm{N}$ in soil during incubation}

Mineral $\mathrm{N}$ increased with progression of the incubation period for all depths although significantly lower in the $15-30 \mathrm{~cm}$ depth. A lag phase was observed in $\mathrm{N}$ mineralization in the first 15 days of incubation in the $\mathrm{C}$ treatment at the 0-15 and 15-30 cm depths (Figures 1 and 2), whereas for the other treatments mineral $\mathrm{N}$ accumulation began immediately. The treatments; LNP (0-15 cm depth), NP, LNP, and M (15-30 cm depth) registered a gradual increase in mineral $\mathrm{N}$ during the first 15 days with the remaining treatments showing a steep increase in mineral $\mathrm{N}$ within the same period (Figure 1 and 2). Between day 15 and 30, rapid $N$ mineralization was realized but tipped off towards the 240 days of incubation (Figure 1 and 2).

For the LMNP, MNP, LM and L treatments, there were sharp increases in mineral $\mathrm{N}$ up to the $30^{\text {th }}$ day. The NP treated samples, however, showed a different pattern of mineralization with respect to other treatments. From the onset of incubation to the end, $\mathrm{N}$ mineralization increased gradually in all depths with mineralization rates of 0.9 and $0.8 \mu \mathrm{g} \mathrm{N} / \mathrm{g}$ dry soil/day for the $0-15$ and $15-30 \mathrm{~cm}$ depths, respectively. The total $\mathrm{N}$ mineralized $(0-30 \mathrm{~cm} \mathrm{depth,} \mu \mathrm{gN} / \mathrm{g}$ dry soil) during the incubation period followed the order: LMNP (720.3), MNP (620.8) LM (602.2), M (562.9), L (564.7), LNP (530.5), C (524.4) and NP (423), with treatments LMNP, MNP, LM and M registering significantly $(\mathrm{P}<0.5)$ higher total mineralized $\mathrm{N}$.

The gradient decrease in mineral $\mathrm{N}$ with depth for all treatments would be due to decreasing organic matter with depth. Similar trends had also been observed by Lelei et al. (2006) who had attributed the decline in organic matter reduction with depth increase. Drissner et al. (2007) and Venkateswarlu et al. (2007) had also observed increased microbial biomass carbon in the upper soil layer and attributed the same to increased availability of substrate carbon that stimulated microbial growth.

The lag period observed in the $\mathrm{C}$ treatments during the first two weeks could be attributed to the soil acidity leading to lack of $\mathrm{N}$ mineralization stimulation. According to De Boer and Kowalchuk (2001), growth of nitrifying bacteria populations is strongly reduced in acidic soils hence low nitrifying potential of the soil. The effect of acidity on nitrification is through the toxic effect of active aluminium ions which inhibit microbial activity and consequently $\mathrm{N}$ mineralization (Graham et al. 2002; Sierra, 2006).

\subsubsection{Microbial biomass during incubation}

The trends in MBN and MBC for both depths could distinctly be grouped into three categories; NP and C treatments, slight fluctuation in microbial biomass realized up to the 240 day, LM and LNP treatments gradual increase up to the $60^{\text {th }}$ day followed by slight decrease towards the 240 days of incubation and L, M and LMNP treatments showing sharp and significant $(\mathrm{P}<0.5)$ increases up to the $60^{\text {th }}$ day followed by a slight decrease towards the 240 days of incubation (Figures 3, 4, 5 and 6).

The observed trend of treatments in the levels of MBN and MBC during incubation points out the importance of adding organic substrates (manure) to the soil and equally the amelioration of soil $\mathrm{pH}$ through liming. The addition of manure to the soil stimulated growth and activity of the microbial community simultaneously, while in the control and NP treatments changes in biomass size did not occur at the same time as changes in activity with resultant suppressed mineralization (Barkle et al., 2001).

The declining levels in MBN and MBC for all treatments and depths towards the 240 days of incubation (Figures 3, 4, 5 and 6) may be attributed to low microbial turnover in incubated soils possibly as a result of regulated temperatures and limited carbon supply. Organic substrate and moisture usually declines with incubation period while temperatures increase resulting in reduced microbial activities. Venkateswarlu et al. (2007) had found a decline in microbial biomass during $\mathrm{N}$ mineralization in laboratory incubation while Drissner et al. (2007) reported that MBC size was regulated by substrate and water availability and temperature. 
The significantly low mineral $\mathrm{N}$ in the control and NP treatments could also suggest a limitation in decomposable compounds other than $\mathrm{N}$ in these treatments (most likely $\mathrm{C}$ ), resulting in nutrient supplies too low to sustain microbial cell synthesis and high activity levels. According to Liu, (2005) organic amendments could improve soil physical properties (soil moisture and structural stability), and consequently benefit soil microbial mediated processes.

\subsection{Correlation coefficients}

Correlation analysis was done to determine the relationships (correlation coefficients) between mineral N and MBC and MBN in the field and incubated soil and between field and incubated soil.

Field: The correlations coefficients between mineral N and MBN were positive but non-significant at seedling and maturity stages of maize growth in the $0-15 \mathrm{~cm}$ depth and at seedling and tasselling in the $15-30 \mathrm{~cm}$ depth (Table 3), whereas the correlation between mineral $\mathrm{N}$ and $\mathrm{MBC}$ were positive and non significant at maturity in the $0-15 \mathrm{~cm}$ depth (Table 4) and at seedling and maturity in the $15-30 \mathrm{~cm}$ soil depth (Table 4). The correlation coefficients between MBN and $\mathrm{MBC}$ was positive and significant at all sampling periods in the $0-15 \mathrm{~cm}$ depth and at tasselling in the $15-30 \mathrm{~cm}$ depth (Table 3).

Incubated soils: In the incubated soils, there were positive and significant correlations between MBN and Mineral N for both the 0-15 and 15-30 cm soil depths at all sampling periods (Table 4). The correlation between mineral N and MBC was positive at all sampling periods (Table 4) but only significant at 120 and 240 days of incubation in the $0-15 \mathrm{~cm}$ depth and at all sampling times in the 15-30 cm depth. The correlation coefficients between MBN and MBC were positive at all sampling times and depths (Table 4).

Field vs. incubated soils: The Correlation coefficients in respect of mineral N, MBC and MBN between field and incubated soil (Table 4) were; positive and significant for MBC, at all sampling periods in the $0-15 \mathrm{~cm}$ depth with MBN being positive only in the $15-30 \mathrm{~cm}$ depth at tasselling vs. 180 (date of incubation corresponding to maize tasseling stage) days of incubation. Mineral $\mathrm{N}$ was negative and non-significantly correlated at all depths and sampling periods.

The positive correlations between mineral $\mathrm{N}$ and MBN for the field soils at seedling and maturity stages of maize growth reflect low crop demand for $\mathrm{N}$ at these growth stages. Booth et al. (2005) assembled data on soil characteristics, gross and net $\mathrm{N}$ mineralization rates from 100 studies conducted in forest, grassland, and agricultural system. They found that across a wide range of ecosystems, gross and net $\mathrm{N}$ mineralization rates were positively correlated with MBN. Positive correlation between MBN and $\mathrm{N}$ mineralization has also been reported by other workers (Fisk and Schmidt, 1995; Merila et al., 2002). The negative correlation between N and MBN at tasseling could be due to the high $\mathrm{N}$ demand and uptake by the maize crop. It also indicates that immobilization rates increase with microbial biomass and activity. According to Sano et al. (2006), this partly provides the evidence for the hypothesis that $\mathrm{N}$ cycling and microbial functional diversity is related.

The positive correlations between MBN and mineral N; MBC and mineral N; and MBN and MBC during incubation is attributable to the fact that the dynamics of $\mathrm{N}$ in soil could be closely linked to $\mathrm{C}$ which exists in organic compounds and heterotrophic microbial biomass, which utilize organic $\mathrm{C}$ for energy. This assertion is consistent with previously reported studies (Arunachalam and Arunachalam, 2000; Sharma et al., 2004; Wright et al., 2005) who found a significant positive relationship between $\mathrm{MBN}, \mathrm{MBC}$ and mineral $\mathrm{N}$ in incubated conditions.

The positive and significant correlations observed in laboratory and field studies with respect to $\mathrm{MBC}$ in the $0-15 \mathrm{~cm}$ depth for the corresponding maize growth stage and incubation sampling periods, is a reflection of the similarity in mineralization pattern. The negative correlations between field and mineral $\mathrm{N}$, however, points to the dynamic nature of mineral N. Processes such as plant uptake, leaching, immobilization and denitrification determine the availability of mineral N (Scherer et al., 1992) to field crops. The correlation coefficients for MBN were positive but non-significant, except at tasseling, in the $0-15 \mathrm{~cm}$ depth. This could be due to plant uptake coupled with decline in substrate.

\subsection{Effect of treatments on maize yield}

Average maize grain yield ranged from 3067 to $4387 \mathrm{~kg} / \mathrm{ha}$ across the treatments with LMNP giving the highest yield followed by MNP, NP and M treatments. Grain yield increases above control were 31.1, 25.3, 36.4, 3.0, 21.9, 13.7, and $43 \%$ for NP, M, MNP, L, LNP, LM and LMNP treatments, respectively (Figure 7).

There were significant increases in maize grain yield with application of NP fertilizers and manure. This may be attributed to the readily available $\mathrm{N}$ and $\mathrm{P}$ nutrients supplied by the fertilizers applied. This is in addition to manure's effectiveness in acidity regulation and binding of exchangeable $\mathrm{Al}$ in this acid soil. Tejada et al. (2006) reported that manure is a good fertilizer on soil that requires $\mathrm{P}$ and $\mathrm{N}$ to produce high yields. This is attributed to manure's slow release of plant nutrients and contents of $\mathrm{N}$ and $\mathrm{P}$. The control treatment had the lowest maize yields probably because of reduced nitrification rates and fixation of $\mathrm{P}$ in the acid soil that rendered $\mathrm{N}$ and $\mathrm{P}$ unavailable hence limited uptake by the maize crop and consequently poor performance. Low yields could also be attributed to Al saturation. Yamoah et al. (1996) attributed $44 \%$ reduction in maize yield to Al saturation in acid soils. Maize grain yields increases over control 
across treatments followed a similar trend as in mineral $\mathrm{N}$ and microbial biomass (Figures 1, 2, 3, 4, 5 and 6). The treatments to which $\mathrm{M}$ was applied had higher microbial biomass, mineral $\mathrm{N}$ and maize yields thus underscoring the importance of soil microbial biomass in nutrient cycling and plant nutrition.

\section{Conclusions}

Results from the present study have demonstrated that the acid soil management practices applied for maize production had a profound influence on mineral $\mathrm{N}$ and microbial biomass. The substrate and nutrient limitation of microbial biomass (MBN and MBC) and their central role in nutrient cycling in acid soils could be enhanced through application of soil amendments. Our data suggest that LMNP, MNP and M treatments were more effective in enhancing soil microbial biomass, mineral $\mathrm{N}$ and consequently enhanced maize yields. Overall, the effectiveness of the imposed treatments in acid soil management were in the order of MNP, LMNP, LM, NP, LNP and L. The acid soils of Molo thus need manure in combination with NP fertilizer and lime to improve their physicochemical and biological properties and consequently their productivity. In light of the findings of the current study, it is evident that combining organic amendments $\left(5 \mathrm{t} \mathrm{ha}^{-1}\right.$ of manure and $2.5 \mathrm{t} \mathrm{h}^{-1}$ of limes) with chemical fertilizer $\left(60 \mathrm{~kg} \mathrm{ha}^{-1}\right.$ of TSP and $50 \mathrm{~kg} \mathrm{ha}{ }^{-1}$ of Urea) would be a promising alternative in developing more sustainable acid soil management strategy.

\section{Acknowledgments}

We appreciate the kind permission by the Kenya Agricultural Research Institute, Molo to use their experimental fields and the Chairman, Soil Science Department, Egerton University for providing the laboratory facilities for conducting the incubation studies.

\section{References}

Arunachalam, A. and Arunachalam, K. (2000). Influence of gap size and soil properties on microbial biomass in a subtropical humid forest of north-east India. Plant and Soil, 223: 185-193.

Azam, F., S. Farooq and A. Lodhi. (2003). Microbial biomass in agricultural soils-determination, synthesis, dynamics and role in plant nutrition. Pakistan J. Biol. Sci., 6: 629-639.

Barkle, G.F., Stenger, R., Sparling, G.P., Painter, D.J. (2001). Immobilisation and mineralisation of carbon and nitrogen from dairy farm effluent during laboratory soil incubations. Austr. J. Soil Res., 39: 1407-1417.

Bending, G.D., Turner, M.K., Jones, J.E. (2002). Interactions between crop residue and soil organic matter quality and the functional diversity of soil microbial communities. Soil Biol. Biochem., 34: 1073-1082.

Booth, M.S., Stark, J.M., Rastetter, E. (2005). Controls on nitrogen cycling in terrestrial ecosystems: a synthetic analysis of literature data. Ecol. Monogr., 75: 139-157.

Bremner, E. and van Kessel, C. (1992). Plant - available nitrogen from lentil and wheat residues during a subsequent growing season. Soil Sci. Soc. Am. J., 56: 1155-1160.

Brookes, P.C. (1995). The use of microbial parameters in monitoring soil pollution by heavy metals. Biol. Fertil. Soils, 19: 269-279.

Brookes, P.C., Kragt, J.F., Powlson, D.S., Jenkinson, D.S. (1985). Chloroform fumigation and the release of soil nitrogen: the effects of fumigation time and temperature. Soil Biol. Biochem., 17: 831-835.

Buchanan, M.A. (1990). Carbon and phosphorus cycling in no-till and reduced chemical input maize agoecosystems. Experimental and simulation analysis. Ph.D. diss. North Carolina State Univ., Raleigh.

Černý, J., Balík, J., Pavlíková, D., Zitková, M., Sýkora, K. (2003). The influence of organic and mineral nitrogen fertilizers on microbial biomass nitrogen and extractable organic nitrogen in long-term experiments with maize. Plant Soil Environ., 49: 560-564.

Chen, C.R., Xu, Z.H., Mathers, N.J. (2004). Soil carbon pools in adjacent natural and plantation forests of subtropical Australia. Soil Sci. Soc. Am. J., 68:282-291.

Cheruiyot, E.K., Mumera, L.M., Nakhone, L.N. and Mwonga, S.M. (2003). Effect of legume managed fallows on soil nitrogen in following maize (Zea mays L.) and wheat (Triticum aestivum) crops in the Rift Valley highlands of Kenya. Eur. J. of Exp. Agr., 43: 597-604.

Curtin, D., Campbell, C.A., Jalil, A. (1998). Effects of acidity on mineralization: pH-dependence of organic matter mineralization in weakly acidic soils. Soil Biology \& Biochemistry, 30: 57-64.

De Boer W, Kowalchuk GA. (2001). Nitrification in acid soils: microorganisms and mechanisms. Soil Biology and Biochemistry, 33: 853-866.

Doran, J.W., and T.B. Parkin. (1994). Defining and assessing soil quality.p. 3-21. In J.W. Doran (ed.) Defining soil quality for a sustainable environment. SSSA Spec. Publ. 35. SSSA, Madison, WI. 
Drissner, D., Blum, H., Tscherko, D., Kandeler, E. (2007). Nine years of enriched CO2 changes the function and structural diversity of soil microorganisms in a grassland. European Journal of Soil Science, 58: 260-269.

El-Ghamry, A.M., Abid Subhani and El-Naggar, E.M. (2001). Effect of organic residues on soil microbial biomass in different Egyptian soils. Pakistan Jornal of Biological Sciences, 4: 1479-1483.

FAO-UNESCO. (1990). FAO-UNESCO Soil map of the world. Revised legend. World resources. Report, 60 FAO, Rome.

Fauci, M.F. and Dick, R.P. (1994). Plant response to organic amendments and decreasing inorganic nitrogen rates in soil from a long-term experiment. Soil Sci. Soc. Am. J, 58:134-138.

Fisk, M.C., Schmidt, S.K. (1995). Nitrogen mineralization and microbial biomass nitrogen dynamics in 3 Alpine tundra communities. Soil Sci. Soc. Am. J., 59: 1036-1043.

Francisco, J., Calderón, Gregory, W., McCarty and James, B., Reeves. (2005). Analysis of manure and soil nitrogen mineralization during incubation. Biol Fertil Soils, 41: 328-336.

Franzluebbers, A.J., Hons, F.M. and Zuberer, D.A. (1995). Soil organic carbon, microbial biomass and mineralizable carbon and nitrogen in sorghum. Soil Sci. Soc. Am. J., 59: 460-466.

FURP. (1994). Fertilizer Use Recommendations: Volumes 1-23, Kenya Agricultural Research Institute (KARI) Nairobi, Kenya.

Garcia, F.O. and Rice, C.W. (1994). Microbial biomass dynamics in Tall grass Prairie. Soil Sci. Soc. Am. J, 58: 816-823.

Girvan, M.S., Bullimore, J., Pretty, J.N., Osborn, A.M., Ball, A.S. (2003). Soil type is the primary determinant of the composition of the total and active bacterial communities in arable soils. Appl. Environ. Microbiol., 69: 1800-1809.

Graham, M.H., Haynes, R.J., Meyer, J.M. (2002). Changes in soil chemistry and aggregates stability induced by fertilizer application, burning and trash relation on a long-term sugarcane experiment in South Africa. Eur. J. Soil Sci., 53: 589-598.

Gregorich, E.G., B.C. Liang, C.F. Drury, A.F. Mackenzie and W.B. McGill. (2000). Elucidation of the source and turnover of water soluble and microbial biomass carbon in agricultural soils. Soil Biol. Biochem., 32: 581-587.

Groffman, P.M., Rice, C.W. and Tiedje, J.M. (1993). Denitification in tall grass prairie landscape. Ecology. 74: 855-862.

Haney, R.L., A.J. Franzluebbers, F.M. Hons, L.R. Hossner and D.A.Zuberer. (2001). Molar concentration of K2SO4 and soil $\mathrm{pH}$ effect estimation of extractable $\mathrm{C}$ with chloroform fumigation extraction. Soil Biol. Biochem., 33: 1501-1507.

Hole, D.G., Perkins, A.J., Wilson, J.D., Alexander, I.H., Grice, P.V., Evans, A.D. (2005). Does organic farming benefit biodiversity? Biol. Conserv., 122: 113-130.

J“orgensen, R.G. (1996). The fumigation-extraction method to estimate soil microbial biomass: Calibration of the kEC value. Soil Biol. Biochem., 28:25-31.

Kamoni, P.T, Mburu, M.W.K, Gachene, C.K.K. (2000). Influence of irrigation on maize growth, grain yield and nitrogen uptake in a semi-arid environment in Kenya. Paper presented to Soil Science Society of East Africa (SSSEA) conference held in Mombasa, Kenya, 27 November.1 December 2000. SSSEA/ KARI, Nairobi.

Kaye, J.P., Hart, S.C. (1997). Competition for nitrogen between plants and soil microorganisms. Trends Ecol. Evol. 12, 139-143.

Kinraide, T.B. (2003). Toxicity factors in acidic forest soils: attempts to evaluate separately the toxic effects of excessive $\mathrm{Al}^{3+}$ and $\mathrm{H}^{+}$and in sufficient $\mathrm{Ca}^{2+}$ and $\mathrm{Mg}^{2+}$ upon root elongation. Eur. J. Soil Sci., 549: $323-333$.

Kirchner, M. J., A. G. Wollum III, and L. D. King. (1993). Soil microbial populations and activities in reduced chemical input agroecosystems. Soil Sci. Soc. Am. J, 57:1289-1295.

Kladivko, E. J. (2001). Tillage Systems and Soil Ecology. Soil and Tillage Research, 61:61-76.

Lelei, J.J., Onwonga, R.N., Mochoge, B.O. (2006). Interactive effects of lime, manure, N and P fertilizers on maize ( Zea mays L. ) yield and $\mathrm{N}$ and $\mathrm{P}$ uptake in an acid mollic Andosol of Molo Kenya. Egerton Journal: Science and technology series, 6. No. 2: 2006.

Liu, D.L., K.R. Helyar, M.K. Conyers and R. Fisher and G.J. Poile. (2004). Response of wheat, triticale and barley to lime application in semi-arid soils Field Crops Research 90:287-301.

Liu, M. (2005). Biological properties and soil organic matter physical protection of paddy soil under different organic management practices. Ph.D. Thesis. Nanjing Agriucltural University, Nanjing, China, pp. 1-219. 
Magill A.H., Aber J.D. (2000). Variation in soil net mineralization rates with dissolved organic carbon additions. Soil Biology and Biochemistry, 32(5), pp.597-601.

Marschner, P., Kandeler, E., Marschner, B. (2003). Structure and function of the soil microbial community in a long-term fertilizer experiment. Soil Biol. Biochem., 35:453-461.

Mathers, N.J., Mao, X.A., Xu, Z.H., Saffigna, P.G., Berners-Price, S.J., Perera, M.C.S. (2000). Recent advances in the application of C-13 and N-15 NMR spectroscopy to soil organic matter studies. Aust. J. Soil Res., 38: 769-787.

Merila, P., Smolander, A., Strommer, R. (2002). Soil nitrogen transformations along a primary succession transect on the land-uplift coast in western Finland. Soil Biol. Biochem., 34: 373-385.

Poudel, D.D., W.R. Horwath, J.P. Mitch- ell, and S.R. Temple. (2001). Impacts of cropping systems on soil nitrogen storage and loss. Agr. Systems, 68:253-268.

Ros, M., Herna'ndez, M.T., Garcı'a, C. (2003). Soil microbial activity after restoration of a semiarid soil by organic amendments. Soil Biol. Biochem., 35: 463-469.

Sangoi L., Ender M., Guidolin, A.F. Almida L. de. and Konflanzo. A. (2001). Nitrogen fertilization impact on agronomic traits of maize released at different decades. Pesq. Agropec. Bras., Vol. 36 no 5

Sano, S., Yanai, J., Kosaki, T. (2006). Relationships between labile organic matter and nitrogen mineralization in Japanese agricultural soils with reference to land use and soil type. Soil Sci. Plant Nutr., 52: 49-60.

Scherer, H.W., Werner, W. and Rossbach, J. (1992). Effects of pre-treatment of soil samples on N mineralization in incubation experiments. Biol. Fertil. Soils, 14: 135-139.

Sharma, P., S.C. Rai, R. Sharma and E. Sharma. (2004). Effects of landuse change on soil microbial C, N and P in a Himalayan watershed. Pedobiologia, 48: 83-92.

Sierra, J. (2006). A hot-spot approach applied to nitrification in tropical acid soils Soil Biology \& Biochemistry. 38 : 644-652.

Smith, K.A., and S. Li. (1993). Estimation of potentially mineralizable nitrogen in soil by $\mathrm{KCl}$ extraction: I.Comparison with pot experiments. Plant Soil, 157:167-174.

SPSS. (2003). Statistical Package for Social Science Version 11.0. SPSS Inc., Chicago, IL, USA.

Tejada, M., Herna'ndez, M.T., Garci'a, C. (2006). Application of two organic amendments on soil restoration: effects on the soil biological properties. J. Environ. Qual., 35: 1010-1017.

Tsai C.Y., Huber, D.M., Warren, H.L. and Lyznik, A. (2009). Nitrogen uptake and redistribution during maturation of maize hybrids. J. of Food and Agric., 15: 175-187.

Vance, E.D., Brookes, P.C., Jenkinson, D.S. (1987). An extraction method for measuring soil microbial biomass-C. Soil Biol. Biochem., 19: 703-707.

Venkateswarlu, B., Srinivasarao, C.H., Ramesh, G., Venkateswarlu, S., Katyal, J.C. (2007). Effect of long term legume cover crop incorporating on soil organic carbon, microbial biomass, nutrient build - up and grain yields of sorghum/ sunflower under rainfed conditions. Soil Use and Management, 23: 107-113.

Wheeler, D.M., Edmeades, D.C., Morton, J.D. (1997). Effect of lime on yield. N fixation and plant N uptake from the soil by pasture on 3 contrasting trials in New Zealand. New Zealand Journal of Agricultural Research, 40: 397-408.

Wright, A.L., F.M. Hons and J. E. Jr-Matocha. (2005). Tillage impacts on microbial biomass and soil carbon and nitrogen dynamics of corn and cotton rotations. Appl. Soil Ecol., 29: 85-92.

Yamoah, C., Ngueguim, M., Ngong, C., Dias, D.K.W. (1996). Reduction of P fertilizer requirements using lime and mucuna on high P sorption soils of North West Cameroon. Afr. crop sci. J., 4: 441-451.

Yougun, H.E., Qingkui, W., Silong, W. and Xiaojun, Y. (2007). Characteristics of carbon and nitrogen of soil microbial biomass and their relationships with soil nutrients in Cunbnighamia lanceolata plantations. Front. For. China, 2(3): 266 -271 .

Young, I. M. and K. Ritz. (2000). Tillage, Habitat Space and Function of Soil Microbes. Soil and Tillage Research, 53:201-213.

Young-Liang C., Shi-jie H. and Xiang-min S. (2001). Nutrient characteristic in rhizosphere of pure and mixed plantations of Machurian Walnut and Dahurian Larch. J. of For. Res., 12 (3): 18-20.

Zadoks, J.C., T.T. Chang, and C.F. Konzak. (1974). A decimal code for the growth stage of cereals. Weed Res., 14: 415-421. 
Table 1. Mineral N ( $\mu \mathrm{gN} / \mathrm{g}$ dry soil) in soil at the different stages of maize growth (means of 3 observations)

\begin{tabular}{|c|c|c|c|c|}
\hline Treatment & Depth(cm) & Seedling & tasselling & Maturity \\
\hline \multirow[t]{3}{*}{$\mathrm{C}$} & $0-15$ & $20.51(2.90)$ & $16.70(1.24)$ & $9.38(2.40)$ \\
\hline & $15-30$ & $14.20(1.00)$ & $12.20(3.36)$ & $9.90(2.00)$ \\
\hline & Total & $34.71^{\mathrm{cd}}$ & $28.90^{b}$ & $19.28^{\mathrm{cd}}$ \\
\hline \multirow[t]{3}{*}{$\mathrm{L}$} & $0-15$ & $19.50(2.20)$ & $15.90(2.26)$ & $7.80(2.40)$ \\
\hline & $15-30$ & $24.48(3.40)$ & $15.80(4.20)$ & $6.20(0.80)$ \\
\hline & Total & $43.98^{b c}$ & $31.70^{\mathrm{bc}}$ & $14.00^{\mathrm{e}}$ \\
\hline \multirow[t]{3}{*}{ M } & $0-15$ & $16.42(0.62)$ & $13.70(2.96)$ & $8.60(2.23)$ \\
\hline & $15-30$ & $21.43(2.30)$ & $12.60(1.18)$ & $9.20(1.68)$ \\
\hline & Total & $37.85^{\mathrm{cd}}$ & $26.30^{c}$ & $17.80^{d e}$ \\
\hline \multirow[t]{3}{*}{ NP } & $0-15$ & $36.95(6.50)$ & $22.80(1.87)$ & $13.50(4.60)$ \\
\hline & $15-30$ & $29.60(2.36)$ & $18.90(1.23)$ & $12.50(3.80)$ \\
\hline & Total & $66.55^{\mathrm{a}}$ & $41.70^{a}$ & $26.00^{b}$ \\
\hline \multirow[t]{3}{*}{ LNP } & $0-15$ & $25.65(1.40)$ & $20.60(0.98)$ & $16.28(1.26)$ \\
\hline & $15-30$ & $16.33(1.18)$ & $14.80(2.60)$ & $8.60(1.42)$ \\
\hline & Total & $41.98^{b c}$ & $35.40^{\mathrm{ab}}$ & $24.88^{b c}$ \\
\hline \multirow[t]{3}{*}{ MNP } & $0-15$ & $28.74(1.00)$ & $23.60(0.89)$ & $18.58(2.00)$ \\
\hline & $15-30$ & $19.39(2.36)$ & $17.80(4.20)$ & $13.60(1.68)$ \\
\hline & Total & $48.13^{b}$ & $41.40^{\mathrm{a}}$ & $32.18^{\mathrm{a}}$ \\
\hline \multirow[t]{3}{*}{ LM } & $0-15$ & $15.39(0.62)$ & $12.70(1.00)$ & $12.60(2.28)$ \\
\hline & $15-30$ & $17.35(1.28)$ & $14.30(0.58)$ & $11.60(1.62)$ \\
\hline & Total & $32.74^{\mathrm{d}}$ & $27.00^{c}$ & $24.20^{b c}$ \\
\hline \multirow[t]{3}{*}{ LMNP } & $0-15$ & $22.58(2.24)$ & $18.80(1.47)$ & $12.30(2.30)$ \\
\hline & $15-30$ & $18.40(2.00)$ & $14.20(1.26)$ & $9.80(1.50)$ \\
\hline & Total & $40.98^{\mathrm{bcd}}$ & $33.00^{\mathrm{bc}}$ & $22.10^{\mathrm{cb}}$ \\
\hline
\end{tabular}

Means in a column for the different treatments followed by the same letter are not significantly different according to the LSD mean separation procedure. Figures in parenthesis are standard deviations 
Table 2. MBN ( $\mu \mathrm{gN} / \mathrm{g}$ dry soil) and MBC ( $\mu \mathrm{gC} / \mathrm{g}$ dry soil) at the different stages of maize growth (means of 3 observations)

\begin{tabular}{|c|c|c|c|c|c|c|c|}
\hline \multirow{3}{*}{$\begin{array}{l}\text { Treat-m } \\
\text { ent }\end{array}$} & \multirow{3}{*}{$\begin{array}{l}\text { Depth } \\
(\mathrm{cm})\end{array}$} & \multicolumn{3}{|c|}{$\mathrm{MBN}$} & \multicolumn{3}{|c|}{$\mathrm{MBC}$} \\
\hline & & \multicolumn{3}{|c|}{ Stages of maize growth } & \multicolumn{3}{|c|}{ Stages of maize growth } \\
\hline & & Seedling & Tasselling & Maturity & Seedling & Tasselling & Maturity \\
\hline \multirow[t]{2}{*}{$\mathrm{C}$} & $0-15$ & $28.00(1.65)$ & $18.30(1.56)$ & $23.50(1.65)$ & $179.20(2.46)$ & $131.70(2.00)$ & $183.50(1.63)$ \\
\hline & $15-30$ & $18.40(6.92)$ & $12.60(1.24)$ & $15.20(2.24)$ & $130.70(1.98)$ & $106.20(1.38)$ & $140.10(2.40)$ \\
\hline \multirow[t]{2}{*}{$\mathrm{L}$} & $0-15$ & $29.80(1.18)$ & $20.90(2.68)$ & $26.20(1.13)$ & $202.60(1.13)$ & $156.80(1.12)$ & $214.50(3.23)$ \\
\hline & $15-30$ & $21.90(2.60)$ & $15.10(2.32)$ & $16.40(2.50)$ & $160.30(2.50)$ & $128.50(2.56)$ & $156.20(1.00)$ \\
\hline \multirow[t]{2}{*}{ M } & $0-15$ & $53.84(2.24)$ & $37.80(4.21)$ & $45.00(3.20)$ & $382.30(1.49)$ & $290.70(3.38)$ & $382.80(2.00)$ \\
\hline & $15-30$ & $19.40(3.12)$ & $16.40(0.98)$ & $17.40(4.80)$ & $242.50(2.68)$ & $208.40(4.56)$ & $231.30(4.64)$ \\
\hline \multirow[t]{2}{*}{ NP } & $0-15$ & $50.02(2.16)$ & $31.70(2.40)$ & $40.51(3.64)$ & $260.20(3.21)$ & $190.30(1.46)$ & $272.70(1.98)$ \\
\hline & $15-30$ & $38.40(1.16)$ & $15.70(3.62)$ & $15.40(2.81)$ & $238.20(4.16)$ & $119.10(1.72)$ & $123.50(1.30)$ \\
\hline \multirow[t]{2}{*}{ LM } & $0-15$ & $40.06(2.42)$ & $25.50(1.12)$ & $35.53(0.98)$ & $260.40(2.34)$ & $181.10(3.64)$ & $280.70(2.92)$ \\
\hline & $15-30$ & $26.70(1.60)$ & $17.40(1.12)$ & $25.90(1.21)$ & $210.70(6.20)$ & $142.80(2.81)$ & $225.20(2.46)$ \\
\hline \multirow[t]{2}{*}{ LNP } & $0-15$ & $35.40(2.24)$ & $21.90(1.00)$ & $31.90(0.50)$ & $248.10(3.84)$ & $164.30(4.63)$ & $268.50(2.52)$ \\
\hline & $15-30$ & $26.70(3.25)$ & $15.40(0.98)$ & $21.20(2.80)$ & $208.70(4.23)$ & $126.50(2.23)$ & $210.30(3.36)$ \\
\hline \multirow[t]{2}{*}{ MNP } & $0-15$ & $41.40(1.00)$ & $29.50(2.60)$ & $36.70(1.16)$ & $388.90(1.18)$ & $298.20(1.12)$ & $396.10(4.28)$ \\
\hline & $15-30$ & $18.90(1.12)$ & $16.40(1.26)$ & $16.80(2.21)$ & $246.70(1.53)$ & $225.30(1.73)$ & $238.30(2.60)$ \\
\hline \multirow[t]{2}{*}{ LMNP } & $0-15$ & $54.40(3.63)$ & $34.90(1.35)$ & $42.20(2.30)$ & $402.20(1.64)$ & $268.30(3.26)$ & $388.60(2.28)$ \\
\hline & $15-30$ & $23.10(1.20)$ & $19.90(2.45)$ & $19.40(1.80)$ & $282.10(2.38)$ & $256.80(1.38)$ & $267.60(2.00)$ \\
\hline
\end{tabular}

Figures in parenthesis are standard deviations

Table 3. Correlations coefficients of mineral N, MBC and MBN for the field and incubation studies

\begin{tabular}{llllllll}
\hline Parameter & Soil depth & \multicolumn{3}{c}{ Maize growth stages } & \multicolumn{3}{c}{ Incubation period (days) } \\
\cline { 3 - 7 } & & seedling & tasseling & maturity & 30 & 120 & 240 \\
\hline Min N vs. MBN & $0-15 \mathrm{~cm}$ & 0.133 & -0.199 & 0.129 & $0.888^{* *}$ & $.899^{* *}$ & $0.884^{* *}$ \\
& $15-30 \mathrm{~cm}$ & 0.691 & 0.036 & -0.034 & $0.825^{*}$ & $.947^{* *}$ & $0.953^{* *}$ \\
Min N vs. MBC & $0-15 \mathrm{~cm}$ & -0.356 & -0.529 & 0.065 & 0.595 & $0.763^{*}$ & $0.783^{*}$ \\
& $15-30 \mathrm{~cm}$ & 0.196 & -0.391 & 0.008 & $0.896^{* *}$ & $0.824^{*}$ & $0.873^{* *}$ \\
MBN vs. MBC & $0-15 \mathrm{~cm}$ & $0.805^{*}$ & $0.851^{* *}$ & $0.841^{* *}$ & $0.829^{*}$ & $0.927^{* *}$ & $0.947^{* *}$ \\
& $15-30 \mathrm{~cm}$ & 0.239 & $0.769^{*}$ & 0.530 & $0.866^{* *}$ & $0.946^{* *}$ & $0.957^{* *}$ \\
\hline
\end{tabular}

Key:* - correlation significant at 0.05 level ( 2 tailed) ** - correlation significant at 0.01 level (2 tailed)

Table 4. Correlation coefficient of mineral N, MBN and MBN for the field and incubated soil

\begin{tabular}{llccc}
\hline Parameter & Soil depth & $\begin{array}{c}\text { Seedling vs.60 days } \\
\text { of incubation }\end{array}$ & $\begin{array}{c}\text { Tasseling vs. 180 days } \\
\text { of incubation }\end{array}$ & $\begin{array}{c}\text { Maturity vs. 240 days of } \\
\text { incubation }\end{array}$ \\
\hline Mineral N & $0-15 \mathrm{~cm}$ & -0.618 & -0.447 & -0.072 \\
& $15-30 \mathrm{~cm}$ & -0.575 & -0.424 & -0.219 \\
MBN & $0-15 \mathrm{~cm}$ & 0.486 & 0.516 & 0.557 \\
& $15-30 \mathrm{~cm}$ & -0.147 & $0.794^{*}$ & 0.631 \\
MBC & $0-15 \mathrm{~cm}$ & $0.712^{*}$ & $0.750^{*}$ & $0.780^{*}$ \\
& $15-30 \mathrm{~cm}$ & 0.465 & 0.678 & $0.815^{*}$ \\
\hline
\end{tabular}

*correlation significant at 0.05 level (2 tailed) ** - correlation significant at 0.01 level (2 tailed) 


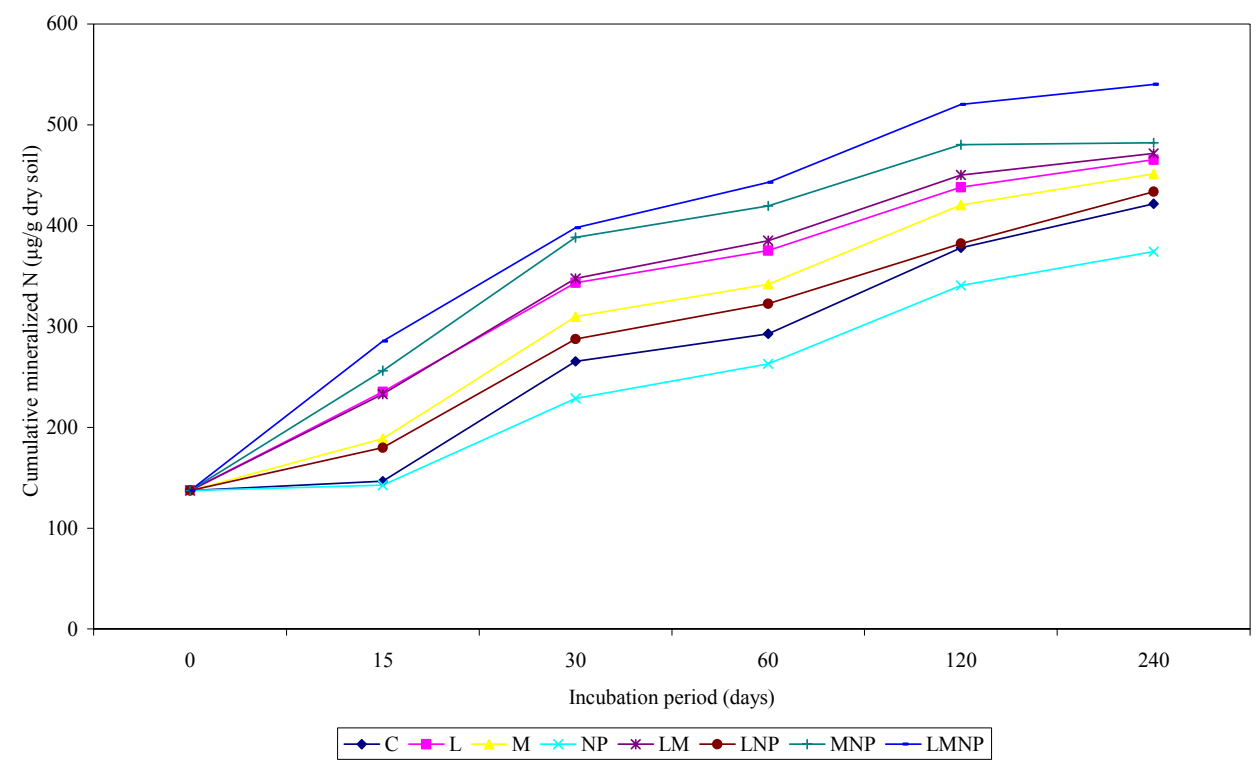

Figure 1. Cummulative mineral $\mathrm{N}(\mu \mathrm{g} / \mathrm{g}$ dry soil) at the $0-15 \mathrm{~cm}$ depth

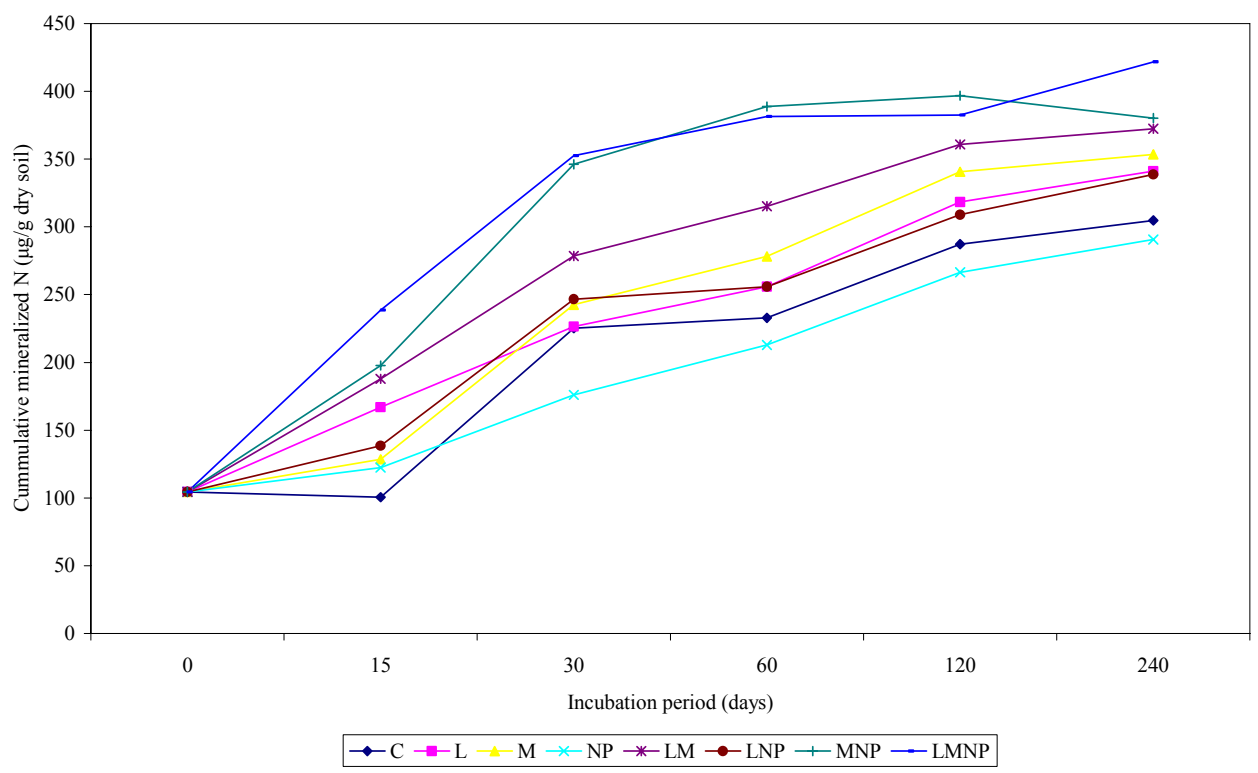

Figure 2. Cummulative Mineral N ( $\mu \mathrm{g}$ g dry soil) at the $15-30 \mathrm{~cm}$ depth 


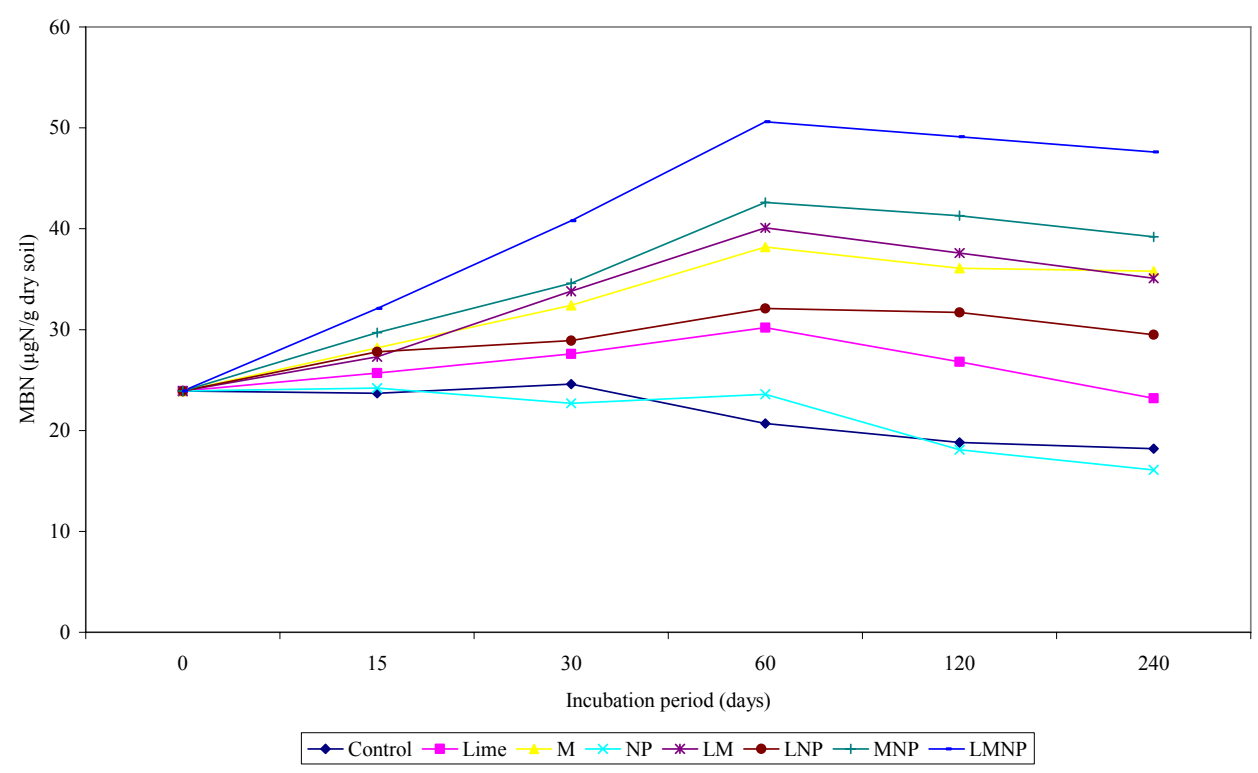

Figure 3. MBN ( $\mu \mathrm{g} \mathrm{N} / \mathrm{g}$ dry soil $)$ at the $0-15 \mathrm{~cm}$ soil depth

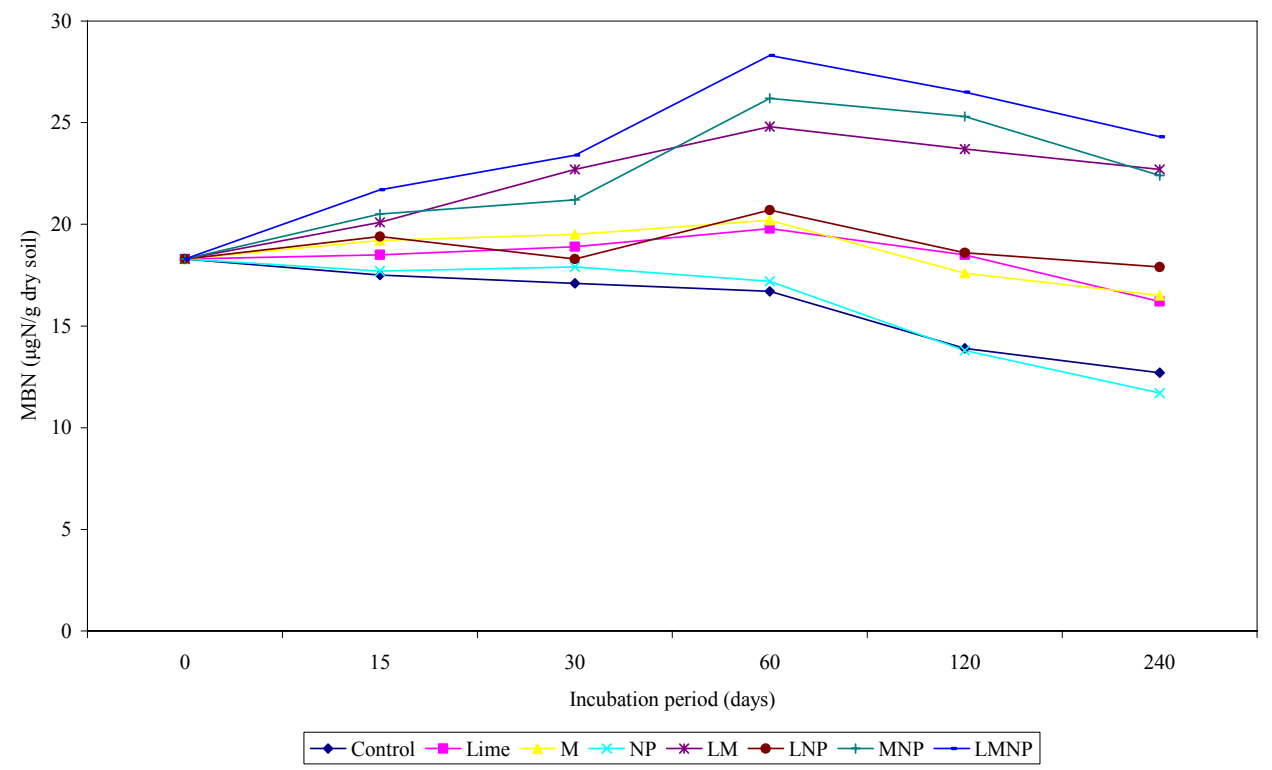

Figure 4. MBN ( $\mu \mathrm{g} \mathrm{N} / \mathrm{g}$ dry soil $)$ at the $15-30 \mathrm{~cm}$ soil depth 


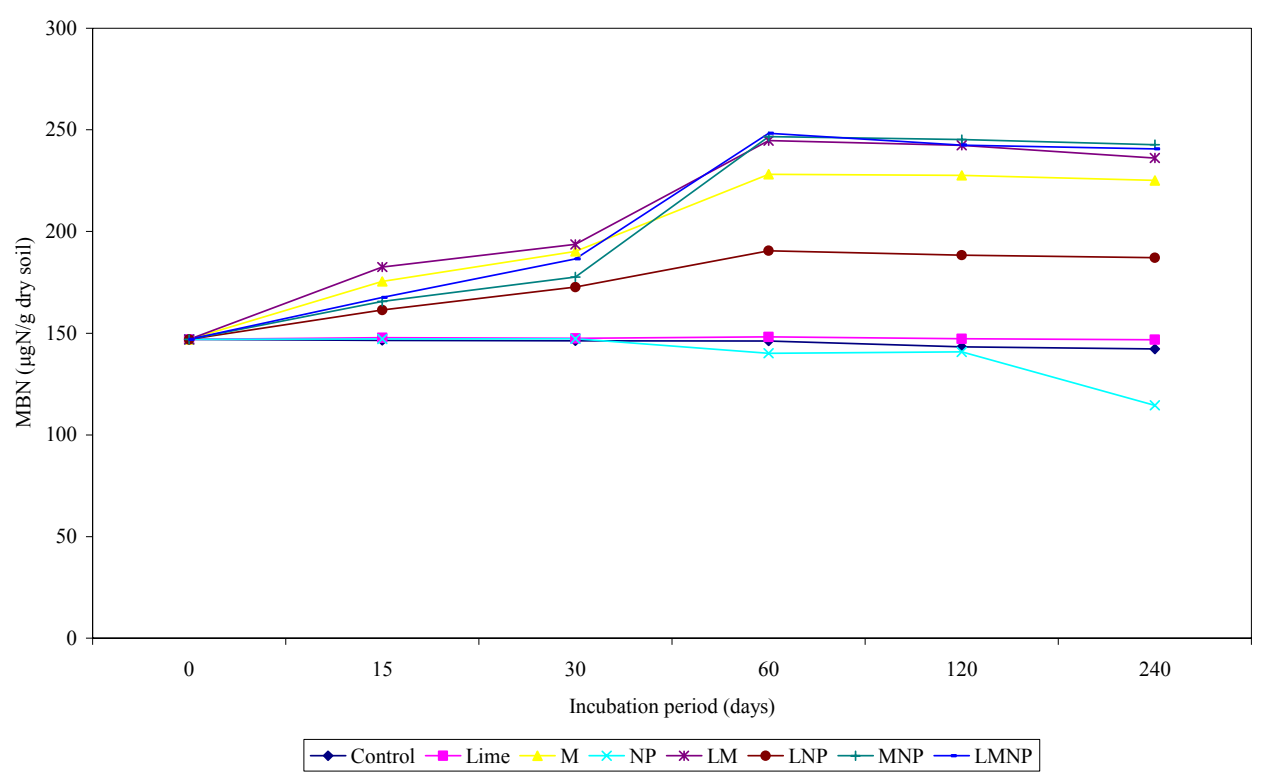

Figure 5. MBC ( $\mu \mathrm{g} \mathrm{C} / \mathrm{g}$ dry soil $)$ at the $0-15 \mathrm{~cm}$ soil depth

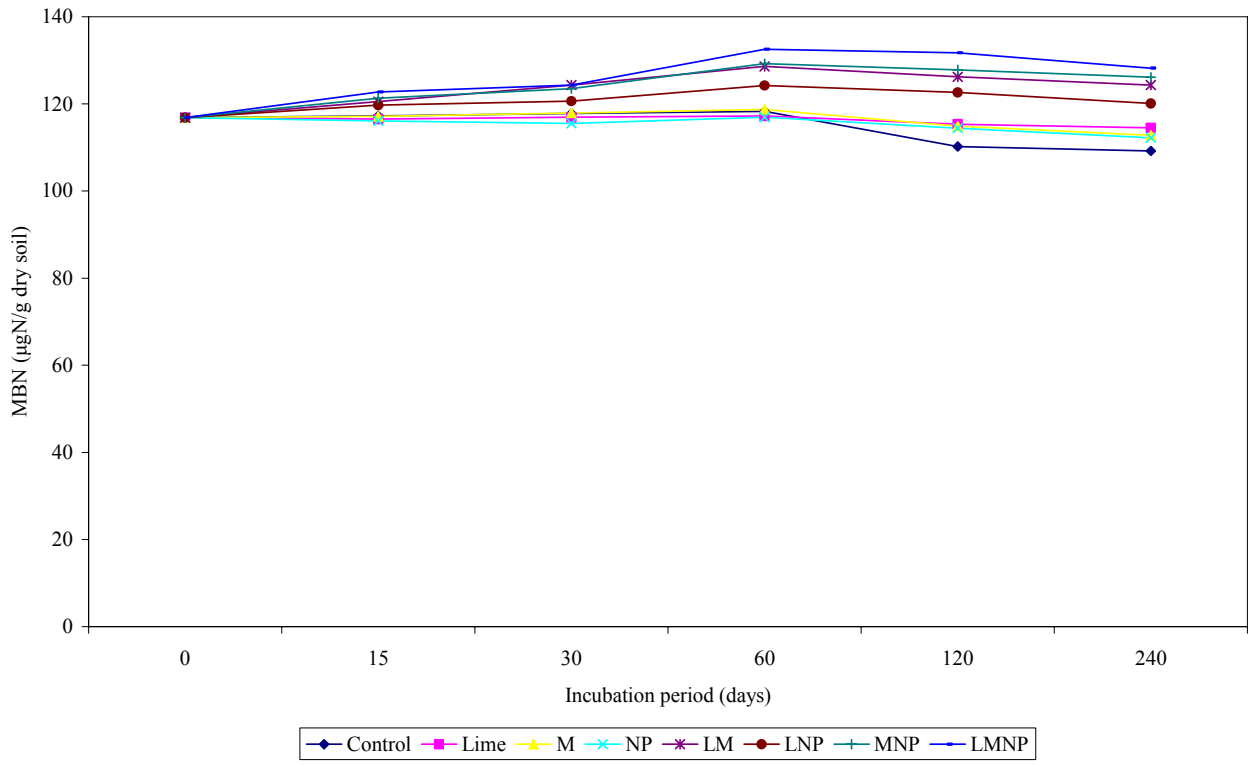

Figure 6. MBC ( $\mu \mathrm{g} \mathrm{C} / \mathrm{g}$ dry soil $)$ at the $15-30 \mathrm{~cm}$ soil depth 


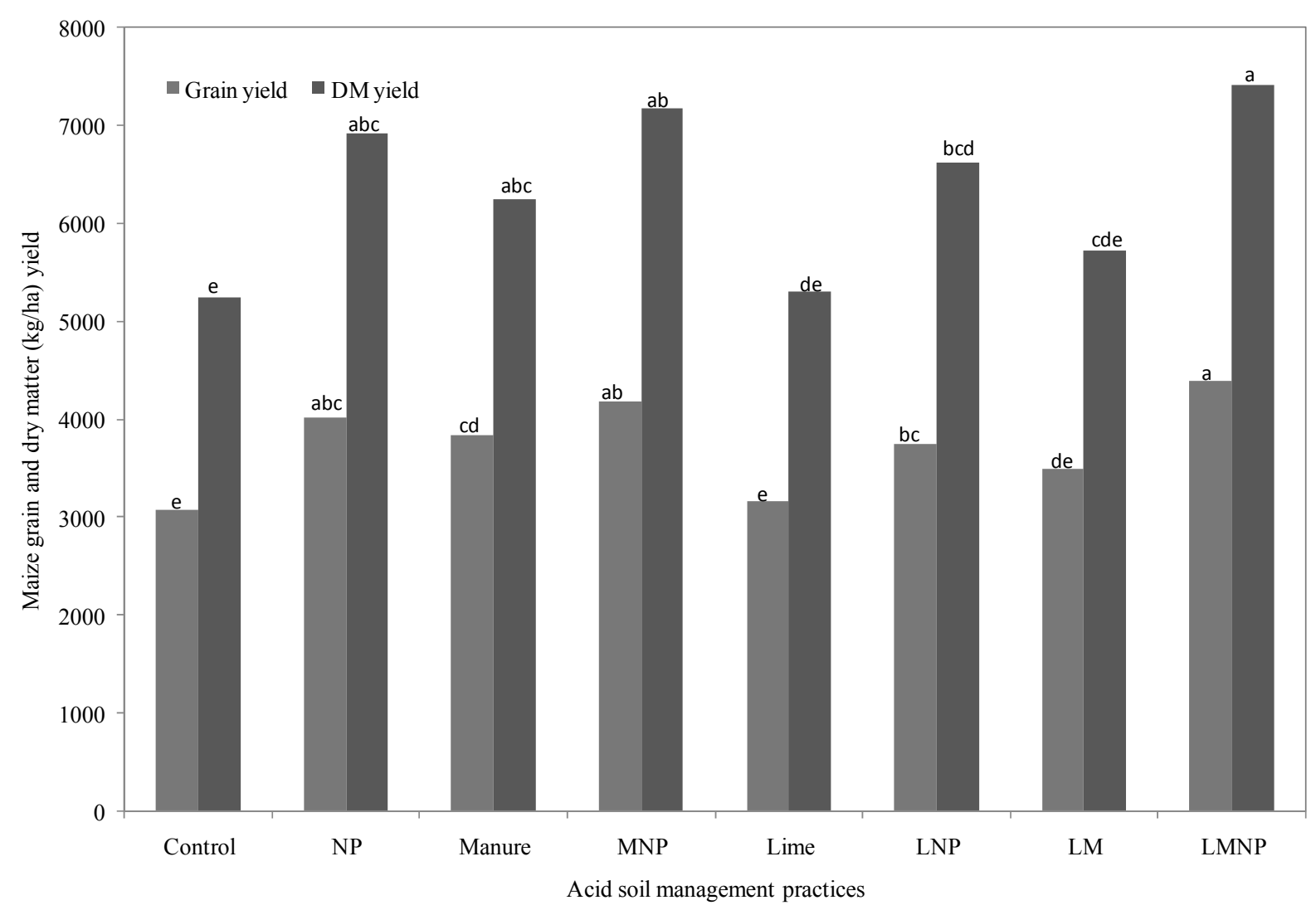

Figure 7. Means of maize grain and DM yield ( $\mathrm{kg} / \mathrm{ha}$ ) as affected by the different treatments (means of 3 observations) Means of maize yield for each soil amendement followed by the same letter are not significantly different according to LSD mean separation procedure, $\mathrm{P}<0.05$ 